\title{
Initial growth and physiological indexes of Fig accessions in active germoplasm bank
}

\author{
Maria Gabriela Fontanetti Rodrigues ${ }^{1}$, Antonio Flávio Arruda Ferreira², Laís Naiara Honorato Monteiro ${ }^{3}$, \\ Tatiane Paes dos Santos ${ }^{4}$, Lucas Aparecido Manzani Lisboa ${ }^{5}$, Paulo Alexandre Monteiro de Figueiredo ${ }^{6}$
}

\begin{abstract}
Fruit growing has become an important alternative economic strategy for the social reproduction of small rural producers. Fig (Ficus carica L.) is a fruit of great world importance, and can be used as a new source of agricultural variability, adding advantages, both economically and socially. In addition, the characterization of active germplasm banks of the genus Ficus becomes an important research line for culture improvement, and it is necessary to gather information, mainly in relation to its genetic variability, so that adequate propagation and management projects are carried out. Therefore, the aim of this work was to establish and characterize an active germplasm bank of fig tree by means of the morphophysiological descriptors of 45 fig accessions, with a randomized complete block design at the Faculty of Agrarian and Technological Sciences, Campus of Dracena, FCAT / UNESP. To do so, the biometric features of re-growth, relative growth rate, plant height and morphophysiological characteristics of the best performance accessions during their vegetative development were evaluated. It could be concluded that most accessions presented good adaptation to the implantation region, especially accessions 18, 28, 29, 30 and 31, which were more promising.
\end{abstract}

Index terms: Ficus carica L., conservation of genetic resources, morphophysiology.

\section{Crescimento inicial e índices fisiológicos de acessos de figueira em banco ativo de germoplasma}

Corresponding author: maria.gf.rodrigues@unesp.br

Received: November 30, 2018 Accepted: May 30, 2019

Copyright: All the contents of this journal, except where otherwise noted, is licensed under a Creative Commons Attribution License.

\section{(cc) $\mathbf{E} \mathrm{Y}$}

Resumo- A fruticultura constitui-se em importante estratégia econômica alternativa para a reprodução social dos pequenos produtores rurais. A figueira (Ficus carica L.) é uma frutífera de grande importância mundial, podendo ser implantada como nova fonte de variabilidade agrícola, agregando vantagens, tanto do ponto de vista econômico quanto social. Adicionalmente, a caracterização dos bancos ativos de germoplasma do gênero Ficus torna-se uma linha de pesquisa importante para a melhoria da cultura, sendo necessário reunir informações, para que projetos de propagação e manejo adequados sejam realizados. Diante disso, o objetivo do presente trabalho foi realizar o estabelecimento e a caracterização de um banco ativo de germoplasma da cultura da figueira por meio de caracteres morfofisiológicos de 45 acessos de figo, com delineamento experimental em blocos casualizados, na Faculdade de Ciências Agrárias e Tecnológicas, Câmpus de Dracena, FCAT/UNESP. Para tanto, foram avaliadas suas características biométricas de rebrota, taxa de crescimento relativo, altura das plantas e características morfofisiológicas dos acessos de melhor desempenho durante seu desenvolvimento vegetativo. Pôde-se concluir que a maioria dos acessos apresentou boa adaptação à região de implantação, com destaque para os acessos $18 ; 28$; 29; 30 e 31, que se mostraram mais promissores.

Termos para indexação: Ficus carica L., conservação de recursos genéticos, morfofisiologia. 


\section{Introduction}

Fig, Ficus carica L., is a fruit tree belonging to the family Moraceas, which, despite being considered of temperate climate, by appropriate pruning and irrigation, adapts to a wide climatic diversity and can be cultivated both in warm subtropical as in tropical regions (PEREIRA, 1981).

The fruit activity, as an economic alternative, has become an important strategy for the social reproduction of small rural producers, as opposed to the technification process of the Brazilian agriculture. Thus, the region of Dracena-SP stands out for the expressiveness of its fruit growing activity, emphasizing grape and acerola cherry crops, followed by passion fruit, banana and mango (CETESB, 2016).

According to Barolo, Mostacero and López (2014), in addition to its economic expression and participation in diet supplementation, being an important source of vitamins and minerals, fig has been used to improve health conditions.

In addition, the Brazilian fig harvest occurs in a period of off-season production of fresh fruit in the Northern Hemisphere and in the other Mercosur countries. Thus, export possibilities are wide, since the Brazilian product enters the international market from December, soon after the harvest of Mediterranean countries (LEONEL and TECCHIO, 2008).

In Brazil, there is predominance of 'Roxo-deValinhos' cultivar, which presents serious problems related to pests and diseases due to the small genetic variability, hindering its cultivation and depreciating fruits, reducing profits and demanding high expenses with inputs and cultural practices (CORREA and BOLIANI, 1999).

Therefore, the selection and recovery of genotype that associates the basic characteristics of the original cultivar with those intended to be introduced become very difficult, demonstrating the species vulnerability regarding the narrowing of the genetic base, which can only be avoided with variability, which depends on available genetic resources (CASALI, 1969); that is, the knowledge of its germplasm.

Germplasm is the source of genetic variability available for the breeding of plants, serving as a reservoir of genes that can be accessed to solve specific problems, such as resistance to diseases. According to Nass (2007), the exchange of germplasm among researchers is a way of integrating agrobiodiversity conservation efforts with sustainable development (COSTA et al., 2015).

According to Frankham (2005), genetic diversity becomes the key to species survival and adaptation to changes in the environment. A fundamental task is to elucidate the mechanisms of origin and maintenance of this variation (PLATT et al., 2010; HUANG et al., 2014).

One of the important steps to automatically preserve and conserve biological diversity is to recognize it, understand it, and identify it (KOLIVAND et al., 2018). Thus, according to taxonomy theory, plants could be identified based on their morphological, physiological, cytological, biochemical or molecular characteristics, including attributes, characteristics or traits of a culture (GOËAU et al, 2013).

In view of the above, the aim of the present work was to characterize the morphophysiological development of 45 fig accessions (Ficus carica L.) belonging to the Active Germplasm Bank introduced at the Faculty of Agrarian and Technological Sciences, Campus de Dracena, FCAT / UNESP, allowing the recognition of the quality and potentiality of the genetic variation of this species.

\section{Material and methods}

The genetic material used came from 45 accessions described in Table 1, belonging to the genus Ficus, which compose the one-year-old Fig Active Germoplasm Bank of the Agrarian Sector of the Faculty of Agrarian and Technological Sciences at FCAT / UNESP, Campus of Dracena-SP.

The experimental design was a randomized block, consisting of 45 treatments, each accession being considered one treatment, with two blocks and three plants per plot, totalizing 270 plants, grown in $1.5 \mathrm{~m} \mathrm{x}$ $1.5 \mathrm{~m}$ spacing. Treatments and places of origin are shown in Table 1.

Thirty days before planting, each 40x40x40 cm open pit received $1.0 \mathrm{~kg}$ of limestone and $1.0 \mathrm{~kg}$ of manure as fertilizer. Sixty days after planting, fertilizations were performed according to soil analysis and recommendations of Raijet al. (1997), in the projection of the crown of fig trees, with soil lacking of mulch.

Phytosanitary treatment was carried out with biweekly applications of Bordeaux mixture (1\%), as well as Mancozeb (200g p.c. $/ 100$ liters of water), in order to control fig tree rust (Ceroteliumfici Cast.), alternately applied.

When necessary, weed control was performed by weeding. For irrigation, drippers were used three times a week with average precipitation of $2.0 \mathrm{~mm} / \mathrm{h}$, reaching $50 \mathrm{~cm}$ range in the planting line.

For initial formation, fig plants were conducted in a single stem, being then pruned at $40 \mathrm{~cm}$ height, eliminating the apical dominance and stimulating the emergence of lateral buds.

During vegetative development until plant fruiting, the following were evaluated:

a) Beginning of re-growth, counting the days for the beginning of the development of branches after the first formation pruning. 
b) Plant height at 100 days after emergence, in centimeters;

c) Relative Growth Rate (RGR), considering the increase in the mass of selected branches per original mass unit, measured by their length, in centimeters, every 10 days, using the formula proposed by Benincasa (2003):

$\mathrm{TCR}=(\operatorname{lnR} 2-\operatorname{lnR} 1) / \Delta \mathrm{T}$ where,

$\ln =$ neperian logarithm

$\mathrm{R} 1=$ initial branch length;

$\mathrm{R} 2$ = final branch length;

$\Delta \mathrm{T}=$ period in days that delimits the beginning and end of the branch length measurement.

From results obtained, statistical analysis of all accessions was performed, and averages were grouped by the Scott-Knott test at 5\% probability level. For statistical analysis, the Sisvar software was used: the computer statistical analysis system, version 5.6 (FERREIRA, 2014).

The Relative Growth Rate (RGR) was adjusted with respect to time using a second-degree polynomial equation. This physiological index does not obey the basic assumptions for the analysis of variance. Therefore, data were presented in the form of graphs, evaluating the behavior of curves (BARREIRO et al., 2006).

From height and RGR data, the best adapted accessions were selected to evaluate their physiological indexes using portable photosynthesis meter, IRGA, model LI-6400 (LI-COR). Measurements were performed in the median region of fully expanded leaves when totally exposed to solar radiation, from 02:00 pm to 03:00 pm, and the following characteristics were evaluated:

a) Net $\mathrm{CO}_{2}$ assimilation rate $\left(\mu \mathrm{mol} \mathrm{m} \mathrm{m}^{-2} \mathrm{~s}^{-1}\right.$;

b) Stomatal conductance of leaves $\left(\mathrm{mol} \mathrm{m}^{-2} \mathrm{~s}^{-1}\right)$;

c) Internal $\mathrm{CO}_{2}$ concentration (ppm)

d) Leaf transpiration rate $\left(\mathrm{mmol} \mathrm{m} \mathrm{m}^{-2} \mathrm{~s}^{-1}\right)$;

e) Internal leaf temperature $\left({ }^{\circ} \mathrm{C}\right)$

f) Water use efficiency $\left(\mu \mathrm{mol} \mathrm{mmol}{ }^{-1}\right)$.

\section{Results and discussion}

The beginning of regrowth of plants pruned in July / August occurred at 20 days, when the development of branches was measured for the calculation of the Relative Growth Rate of accessions. Through the SkottKnott test, the clustering analysis of the height of fig plants 100 days after regrowth is found in Table 2.

It was verified that there was a significant difference among treatments, especially for accessions 28 and 29, with 1.25 and 1.27 meters in height, respectively, but did not differ from treatments 5 (Stanford), 6 (Adriático Branco), 10 (Smyrna), 11 (Smyrna), 14 (Pingo de Mel), 16 (Palestino), 18 (Figo Vermelho), 30 (accession 30), 31 (accession 31) and 45 (Turco). Treatment 4 , traditional
"Roxo-de-Valinhos" variety presented average height of 1.01 meters, statistically differing from accessions with greater height.

Treatments 24 (Nazaret), 20 (PI 440), 23 (PI 301), 26 (ISA Roxo-de-Valinhos), 34 (Accession 34 Monte Alto), 41 (Accession 41 Monte Alto) and 22 (PI 214) obtained the lowest height values, which was expected, since most of these accessions come from irradiated stakes. However, accession 24, which presented the lowest value, only $47 \mathrm{~cm}$, although not irradiated, comes from Spain, which presents a different climate, demonstrating that it does not have good climatic adaptation for the regional conditions of Dracena-SP.

Plant growth analysis is a valid technique to study the physiological bases of production and to show the influence exerted by environmental, genetic and agronomic variables, following the dynamics of photosynthetic production evaluated through phytomass accumulation, being widely used to investigate the effect of ecological phenomena on growth as adaptability of species in diverse ecosystems (SILVA et al., 2000).

In relation to the relative growth rate (RGR) of BAG fig tree, it was observed that the behavior of the RGR curve in all treatments, except for treatment 21 (Irradiated Plant 189), with $\mathrm{R}^{2}=0.53$, followed the pattern of rapid material accumulation at the beginning of plant development, followed by decrease along collections, with stabilization trend in $\mathrm{R}^{2}$ values ranging from 0.70 to 0.98 for accessions 11 and 41, respectively, considered values within normality (MARTINS et al., 1985).

The relative growth rate (RGR) reflects the increase in the dry organic matter content of a plant or of any organ in a period of time, being a function of the initial size, that is, of preexisting material (BENINCASA, 2003). For Briggs et al. (1920), this is the most appropriate measure to evaluate plant growth, being dependent on the amount of material being accumulated.

This fact can be explained by the elevation of respiratory activity, by the beginning of fruiting, and by self-shading, which increases with plant age (BARREIRO et al., 2006), causing stabilization in dry matter accumulation after some weeks of growth (GOMIDE et al., 2003).

According to Ferrari et al. (2008), the decrease in RGR during the cycle of flowering plants is expected, because with the increase in the dry phytomass accumulated by plants increases the need of photoassimilates for the maintenance of structures already formed, reducing the amount available for growth. In addition, Comettiet al. (2008), suggest that the decline in RGR indicates the approximation of fruit senescence, at which time net assimilation becomes negative.

For the highest RGR values, treatments 18 (Figo vermelho), 28 (accession 28), 29 (accession 29) and 31 (accession 31), represented in Figure 1, showed the highest 
height values, not statistically differing from each other.

Accession 21, represented in Figure 2A, showed lower value at the beginning of plant development and higher value in the medium collection, reducing again in the last collection, allowing deducing that there is a delay in the development of these plants, differing from the other accessions.

Although showing high RGR indexes, accession 30, shown in Figure 2B, showed negative growth values at 65 days after regrowth, revealing the high respiratory demand in this period, which could represent the consumption of reserves to meet the greater energy demand for maintenance and regrowth.

Treatment 44 (Figo Preto), in figure 2C, maintained the RGR decrease pattern along its development and stood out in relation to the highest RGR values calculated, but did not present relation with plant height, indicating better performance at the initial development period when compared to the other accessions, as elucidated by Silva et al. (2000), analyzing the growth of plant communities.

All phytomass production and formation of the fig tree architecture directly depend on the photosynthetic activity, since the pruning practice is a management adopted in Brazilian orchards, making the plant to present renewal of shoots at each productive cycle (DALASTRA et al. 2009). Thus, the search for more information on the fig tree physiology is of fundamental importance.

With the analysis of previously evaluated factors, fig tree accessions that stood out due to the high or low development were selected for the evaluation of their physiological indexes, which, together, represent the adaptability of plants to the environment in which they are.

There was a statistical difference for the majority of parameters evaluated in relation to gas exchanges, such as net $\mathrm{CO}_{2}$ assimilation rate; stomatal conductance; internal $\mathrm{CO}_{2}$ concentration; transpiration rate and internal leaf temperature in selected Ficus carica L. plants, as shown in Table 3.

Net $\mathrm{CO}_{2}$ assimilation rate, which represents the photosynthesis performed by the plant, varied from 5.75 $\mu \mathrm{mol} \mathrm{m} \mathrm{m}^{-2} \mathrm{~s}^{-1}$ for accession 21 (Irradiated Plant 189) to $13.58 \mu \mathrm{mol} \mathrm{m}^{-2} \mathrm{~s}^{-1}$ for accession 30 .

According to Pimentel (1998), $\mathrm{C}_{3}$ plants demonstrate photosynthetic activity ranging from 12 to $25 \mu \mathrm{mol} \mathrm{m} \mathrm{m}^{-2} \mathrm{~s}^{-1} \cdot \mathrm{C}_{4}$ plants exhibit values ranging from 25 to $40 \mu \mathrm{mol} \mathrm{m}^{-2} \mathrm{~s}^{-1}$. However, depending on environmental conditions, CAM plants show this activity in the range from 2.5 to $7.6 \mu \mathrm{mol} \mathrm{m}{ }^{-2} \mathrm{~s}^{-1}$.

Since fig tree is considered a $\mathrm{C}_{3}$ plant (TING et al, 1987; ZOTZ et al, 1997; CAN and AKSOY, 2007), most selected accessions presented values that can be considered low for the Ficus carica L. species, being only accession 30 within normality. Pigéet al. (2001) evaluated characteristics related to the $\mathrm{CO}_{2}$ exchange in leaves and fruits of one-year-old fig tree branches during the spring- autumn season and observed that the net photosynthesis rate ranged from 15 to $20 \mu \mathrm{mol} \mathrm{m}^{-2} \mathrm{~s}^{-1}$. However, Silva et al. (2010) found results similar to those shown in the present work, with net $\mathrm{CO}_{2}$ assimilation rate in the 'Roxode-Valinhos' cultivar varying from -0.370 to $14.378 \mu \mathrm{mol}$ $\mathrm{m}^{-2} \mathrm{~s}^{-1}$.

Regarding stomatal conductance, the accession that presented the highest value was also accession 30 , with $0.358 \mathrm{~mol} \mathrm{~m}^{-2} \mathrm{~s}^{-1}$, and again, accession 21 (Irradiated Plant 189) was the one with the lowest value, $0.11 \mathrm{~mol}$ $\mathrm{m}^{-2} \mathrm{~s}^{-1}$ (Table 3). Stomatal conductance is closely related to the net $\mathrm{CO}_{2}$ assimilation rate, and low values may be associated to the partial closure of the stomata, being the first reaction of the plant to the occurrence of thermal stress (FLEXAS et al., 2006), and can be explained by the fact that the climate of the region is not the most appropriate for the crop development.

Campostrini and Yamanishi (2001), justify that the correlation between $\mathrm{CO}_{2}$ assimilation and stomatal conductance can be explained due to the high carbon dioxide concentration in the carboxylation sites of the plant. In situations of low stomatal conductance, carbon fixation may be restricted, affecting carbohydrate metabolism and transport along tissues (BEL, 1992).

The increase in photosynthetic rates depends, simultaneously, on the maximum utilization of available light obtained according to the phenological age of leaves and crop management (BERNARDES, 1987).

Thus, another important factor to be taken into account is that the evaluated plants were in the regrowth stage and, according to Silva et al. (2010), young leaves presented the lowest net $\mathrm{CO}_{2}$ assimilation, transpiration and stomatal conductance rates, with high $\mathrm{CO}_{2}$ concentration in the substomatal chamber, associated to low photosynthetic carbon assimilation.

In the present work, it could be observed that the internal $\mathrm{CO}_{2}$ concentration values ranged from $308.5 \mathrm{ppm}$ to $257.0 \mathrm{ppm}$, the highest being found for accession 29 Monte Alto, which did not differ from the other accessions, corroborating values found by Silva et al. (2010) for 'Roxo-de-Valinhos' cultivar, which ranged from 391.58 to $291.92 \mathrm{ppm}$.

Leaf transpiration rate was lower for accession 21 (Irradiated Plant 189), with $4.67 \mathrm{mmol} \mathrm{mol} \mathrm{m} \mathrm{s}_{-2}$, demonstrating greater water retention capacity exhibited for this accession, probably due to the stomatal mechanism functioning. Chaves, Costa and Saibo (2011) reported that stomata guard cells respond to multiple exogenous and endogenous signals, such as luminosity, $\mathrm{CO}_{2}$ concentration, pressure vapor deficit, among others.

Regarding internal leaf temperature, the highest values observed were for treatments PI 189 and accession 28 Monte Alto, statistically differing from the others; however, the other accessions, which do not differ from each other, present values very close to the first ones. 
Organisms have limits of tolerance for temperatures, determined by their particular adaptations, which can vary from very low to those considered extremely high. In particular, fig tree tolerates temperatures from 25 to $40^{\circ}$ C (PEREIRA, 1981).

In Brazil, 'Roxo de Valinhos' fig crops are spread from the coldest regions, such as Rio Grande do Sul to hot regions of the state of Minas Gerais, influenced by the small or no cold requirement to complete the rest period allied to the high and limiting temperature amplitude (SOUZA et al., 2009). Thus, internal leaf temperatures close to or exceeding the maximum limit for an extended period may compromise the different growth and development stages of plants.
Morais, Rossi and Higa (2017) studied the influence of the leaf temperature of Sclerolobium paniculumum Vogel and showed that there was a reduction of $\mathrm{CO}_{2}$ assimilation rates due to the increase in leaf temperature. Larcher (2000) demonstrated that, in addition to the other effects caused by temperature rise, the increase in pressure vapor deficit and decrease in relative humidity intensify transpiration processes. In addition, thermal stress can lead enzymes to denaturation, disfiguring the fit regions of compounds participating in chemical reactions, which leads to loss of their functional activity (BLUM et al., 1982).

The use of cultivars adapted to different climatic conditions, soil and production system is the fundamental principle to obtain increases in productivity and quality of any vegetable (NOGUEIRA et al., 2006). Therefore, the generation of new and more productive cultivars with superior qualitative characteristics has been the major challenge for the breeding of fruit plants, and the characterization of Germoplasm Banks is the initial key to the successful growth and expansion of the fig culture.

Table 1. Description of accessions belonging to the Active Germplasm Bank of fig tree - Faculty of Agrarian and Technological Sciences FCAT / UNESP. Dracena -SP, 2017.

\begin{tabular}{|c|c|c|c|c|c|}
\hline Treatment & Accession & Place of origin & Treatment & Accession & Place of origin \\
\hline 1 & Calimyrna & S.J. Rio Preto & 23 & PI 301 (trat6) & ISA \\
\hline 2 & Nobile & IAC & 24 & Nazaret & Espanha \\
\hline 3 & Genovesco & IAC & 25 & Cuello Negro & Espanha \\
\hline 4 & Roxo-de-Valinhos A & S.S. Paraíso & 26 & Roxo-de-Valinhos B & ISA \\
\hline 5 & Stanford & IAC & 27 & Acesso 27 & Monte Alto \\
\hline 6 & Adriático Branco & IAC & 28 & Acesso 28 & Monte Alto \\
\hline 7 & Bonato & IAC & 29 & Acesso 29 & Monte Alto \\
\hline 8 & White Genova A & S.J. Rio Preto & 30 & Acesso 30 & Monte Alto \\
\hline 9 & White Genova B & IAC & 31 & Acesso 31 & Monte Alto \\
\hline 10 & Smyrna A & IAC & 32 & Acesso 32 & Monte Alto \\
\hline 11 & Smyrna B & S.J. Rio Preto & 33 & Acesso 33 & Monte Alto \\
\hline 12 & Brunswich & IAC & 34 & Acesso 34 & Monte Alto \\
\hline 13 & Caprifigo A & IAC & 35 & Acesso 35 & Monte Alto \\
\hline 14 & Pingo de Mel & ISA & 36 & Acesso 36 & Monte Alto \\
\hline 15 & Roxo-de-Valinhos Gigante & ISA & 37 & Acesso 47 & Bahia \\
\hline 16 & Palestino & Campinas & 38 & Acesso 44 & Piracicaba \\
\hline 17 & Troyano & IAC & 39 & Acesso 46 & Piracicaba \\
\hline 18 & Figo Vermelho & Piracicaba & 40 & Caprifigo B & ISA \\
\hline 19 & PI 440 & ISA & 41 & Acesso 41 & Monte Alto \\
\hline 20 & PI 433 & ISA & 42 & Acesso 42 & Monte Alto \\
\hline 21 & PI 189 & ISA & 43 & Mini Figo & IAC \\
\hline \multirow[t]{2}{*}{22} & PI 214 & ISA & 44 & Figo Preto & Piracicaba \\
\hline & & & 45 & Turco & Campinas \\
\hline
\end{tabular}

Subtitle:

$\mathrm{IAC}=$ Agronomic Research Institute, APTA Fruit Center, Jundiaí - SP

ISA = Municipality of Ilha Solteira - SP

S.S. Paraíso = Municipality of São Sebastião do Paraíso - MG

S.J. Rio Preto $=$ Municipality of São José do Rio Preto - SP 
Table 2. Plant height (AL), in meters of accessions from the Active Germplasm Bank, Faculty of Agrarian and Technological Sciences (FCAT / UNESP). Dracena / SP, 2017.

\begin{tabular}{cccc}
\hline Treatment & AL (m) & Treatment & AL (m) \\
\hline 1 & $0.76 \mathrm{C}$ & 24 & $0.47 \mathrm{D}$ \\
2 & $0.88 \mathrm{~B}$ & 25 & $0.88 \mathrm{~B}$ \\
3 & $0.80 \mathrm{C}$ & 26 & $0.57 \mathrm{D}$ \\
4 & $1.01 \mathrm{~B}$ & 27 & $0.76 \mathrm{C}$ \\
5 & $1.08 \mathrm{~A}$ & 28 & $1.25 \mathrm{~A}$ \\
6 & $1.18 \mathrm{~A}$ & 29 & $1.27 \mathrm{~A}$ \\
7 & $0.91 \mathrm{~B}$ & 30 & $1.14 \mathrm{~A}$ \\
8 & $0.95 \mathrm{~B}$ & 31 & $1.18 \mathrm{~A}$ \\
9 & $0.93 \mathrm{~B}$ & 32 & $0.91 \mathrm{~B}$ \\
10 & $1.10 \mathrm{~A}$ & 33 & $0.89 \mathrm{~B}$ \\
11 & $1.07 \mathrm{~A}$ & 34 & $0.63 \mathrm{D}$ \\
12 & $0.92 \mathrm{~B}$ & 35 & $0.82 \mathrm{C}$ \\
13 & $0.96 \mathrm{~B}$ & 36 & $0.99 \mathrm{~B}$ \\
14 & $1.17 \mathrm{~A}$ & 37 & $1.00 \mathrm{~B}$ \\
15 & $0.84 \mathrm{C}$ & 38 & $0.76 \mathrm{C}$ \\
16 & $1.15 \mathrm{~A}$ & 39 & $0.73 \mathrm{C}$ \\
17 & $1.00 \mathrm{~B}$ & 40 & $0.92 \mathrm{~B}$ \\
18 & $1.12 \mathrm{~A}$ & 41 & $0.63 \mathrm{D}$ \\
19 & $0.76 \mathrm{C}$ & 42 & $0.97 \mathrm{~B}$ \\
20 & $0.48 \mathrm{D}$ & 43 & $0.71 \mathrm{C}$ \\
21 & $0.71 \mathrm{C}$ & 44 & $0.86 \mathrm{~B}$ \\
22 & $0.65 \mathrm{D}$ & 45 & $1.13 \mathrm{~A}$ \\
23 & $0.56 \mathrm{D}$ & - & \\
\hline V.C. $(\%)$ & & 17.05 & \\
\hline Mean $(\mathrm{m})$ & & 0.90 & \\
\hline
\end{tabular}

*Equal letters in the same row do not differ from each other by the Scott-Knott at 5\% probability.

Table 3- Gas exchange of 7 fig accessions (Ficus carica L.). Dracena/SP, 2018.

\begin{tabular}{ccccccc}
\hline Treatments & $\begin{array}{c}\mathrm{Net}^{\mathrm{CO}}{ }_{2} \\
\text { assimilation } \\
\text { rate } \\
\left(\mu \mathrm{mol} \mathrm{m} \mathrm{s}^{-1}\right)\end{array}$ & $\begin{array}{c}\text { Stomatal } \\
\text { conductance } \\
\left(\mathrm{mol} \mathrm{m}^{-2} \mathrm{~s}^{-1}\right)\end{array}$ & $\begin{array}{c}\text { Internal } \mathrm{CO}_{2} \\
\text { concentration } \\
(\mathrm{ppm})\end{array}$ & $\begin{array}{c}\text { Transpiration } \\
\text { rate in leaves } \\
\left(\mathrm{mmol} \mathrm{m}^{-2} \mathrm{~s}^{-1}\right)\end{array}$ & $\begin{array}{c}\text { Internal leaf } \\
\text { temperature } \\
\left({ }^{\circ} \mathrm{C}\right)\end{array}$ & $\begin{array}{c}\text { Water use } \\
\text { efficiency } \\
\left(\mu \mathrm{mol} \mathrm{mmol}^{-1}\right)\end{array}$ \\
\hline Figo Vermelho Pir. & $10.01000 \mathrm{~A}$ & $0.28250 \mathrm{~B}$ & $285.00000 \mathrm{~A}$ & $7.88250 \mathrm{~A}$ & $40.20000 \mathrm{~B}$ & $1.26762 \mathrm{~A}$ \\
PI189 ISA & $5.74500 \mathrm{~B}$ & $0.11000 \mathrm{D}$ & $272.50000 \mathrm{~A}$ & $4.67000 \mathrm{C}$ & $41.75000 \mathrm{~A}$ & $1.22618 \mathrm{~A}$ \\
Acesso 28 Monte Alto & $11.48250 \mathrm{~A}$ & $0.23500 \mathrm{C}$ & $257.00000 \mathrm{~A}$ & $9.08750 \mathrm{~A}$ & $43.40000 \mathrm{~A}$ & $1.27232 \mathrm{~A}$ \\
Acesso 29 Monte Alto & $6.87000 \mathrm{~B}$ & $0.31250 \mathrm{~B}$ & $308.50000 \mathrm{~A}$ & $7.26750 \mathrm{~B}$ & $39.12500 \mathrm{~B}$ & $0.90528 \mathrm{~A}$ \\
Acesso 30 Monte Alto & $13.58750 \mathrm{~A}$ & $0.35750 \mathrm{~A}$ & $266.50000 \mathrm{~A}$ & $7.95250 \mathrm{~A}$ & $39.27500 \mathrm{~B}$ & $1.96570 \mathrm{~A}$ \\
Acesso 31 Monte Alto & $11.73250 \mathrm{~A}$ & $0.31250 \mathrm{~B}$ & $267.75000 \mathrm{~A}$ & $7.15500 \mathrm{~B}$ & $39.27500 \mathrm{~B}$ & $1.67717 \mathrm{~A}$ \\
Figo Preto Piracicaba & $11.44250 \mathrm{~A}$ & $0.32000 \mathrm{~B}$ & $281.25000 \mathrm{~A}$ & $9.27500 \mathrm{~A}$ & $41.10000 \mathrm{~B}$ & $1.24367 \mathrm{~A}$ \\
V.C.\% & 50,36 & 22,38 & 10,27 & 14,06 & 4,32 & 42,00 \\
\hline
\end{tabular}



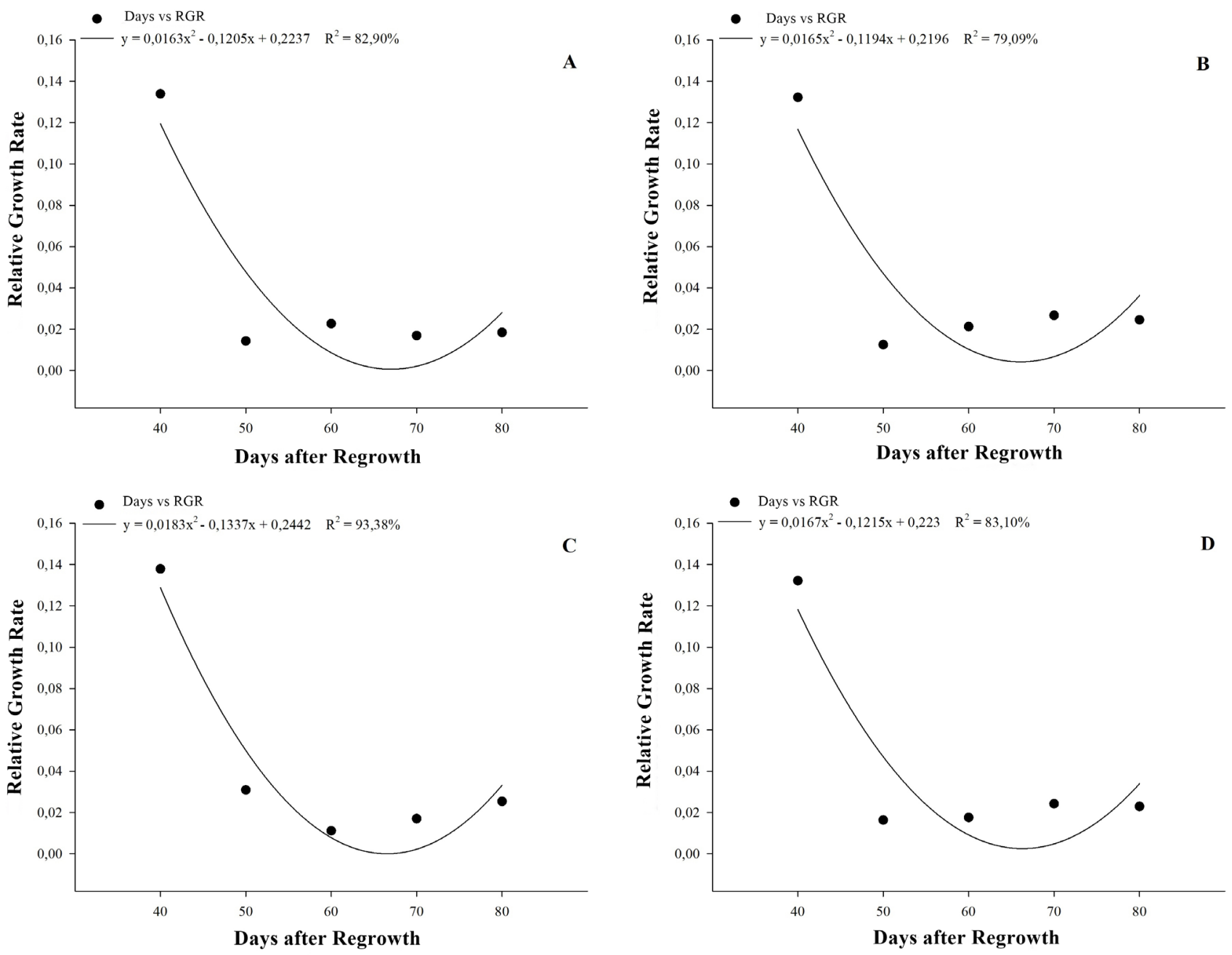

Figure 1. Relative Growth Rate (RGR): Accession 18 - Figo Vermelho de Piracicaba (A), Accession 28 - Monte Alto (B), Accession 29 - Monte Alto (C) and Accession 31 - Monte Alto (D), belonging to the AGB of the Faculty of Agrarian and Technological Sciences FCAT / UNESP. Dracena - SP, 2017. 

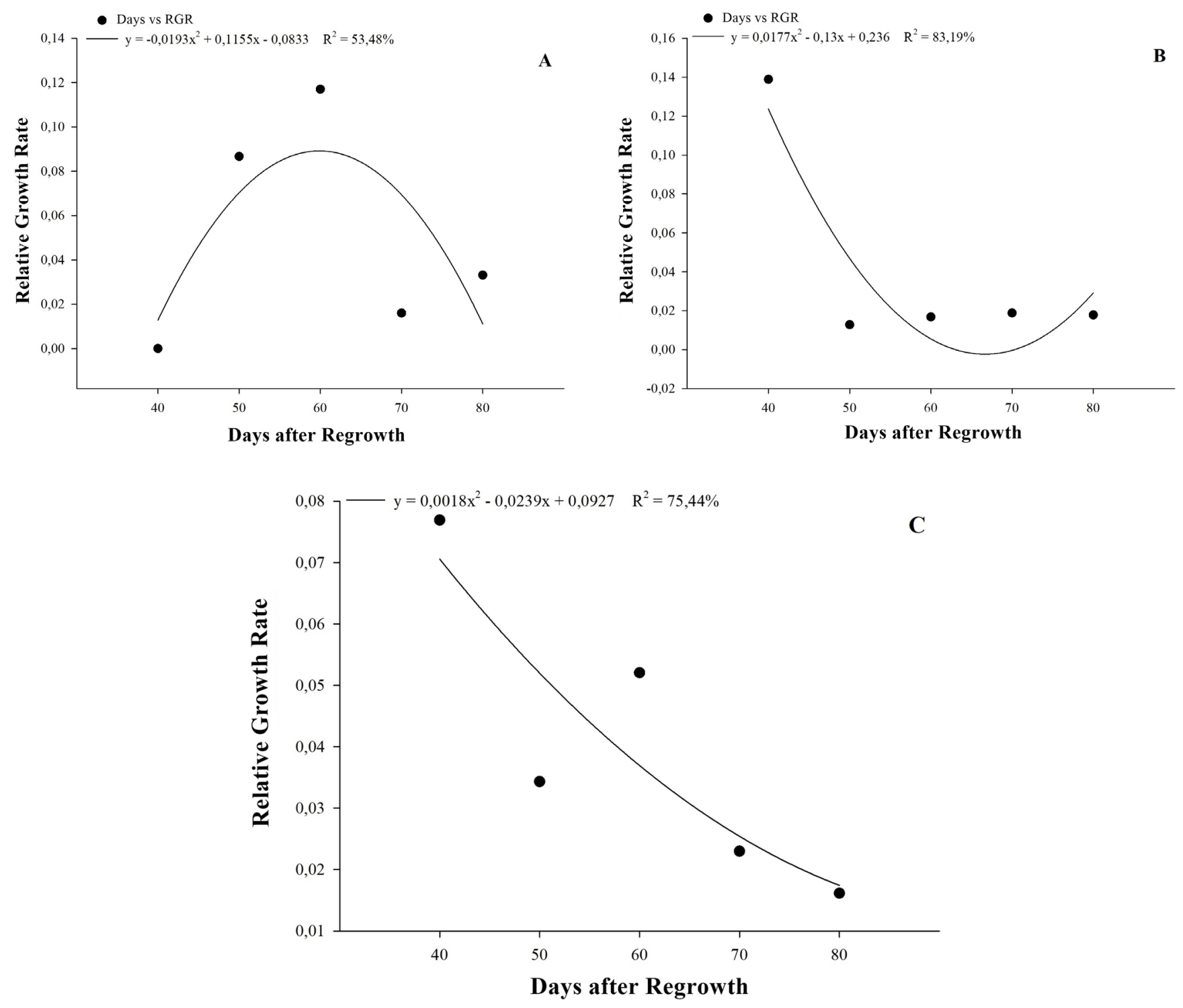

Figure 2. Relative Growth Rate (RGR): Accession 21 - Irradiated plant (A), Accession 30 - Monte Alto (B), Accession 44 - Figo Preto de Piracicaba (C), belonging to the AGB of the Faculty of Agrarian and Technological Sciences FCAT / UNESP. Dracena - SP, 2017. 


\section{Conclusion}

Based on results obtained with respect to the growth and vegetative development of fig tree accessions, it could be concluded that most accessions had good adaptation to the implantation region, especially accessions $18,28,29,30$ and 31 , which were more promising.

\section{Acknowledgments}

To the Foundation for Research Support of the State of São Paulo (FAPESP) for the financial assistance granted to the first author (process number 2016/20418-8) and to the Faculty of Agrarian and Technological Sciences FCAT / UNESP.

\section{References}

BAROLO, M.I.; MOSTACERO, N.R.; LÓPEZ, S.N. Ficus carica L. (Moraceae): An ancient source of food and health. Food chemistry, London, v.164, p.119-127, 2014.

BARREIRO, A.P.; ZUCARELI, V.; ONO, E.O.; RODRIGUES, J.D. Análise de crescimento de plantas de manjericão tratadas com reguladores vegetais. Bragantia, Campinas, v.65, n.4, p.563-567, 2006.

BEL, V.A.J.E. Mechanism of sugar transfer. In: BAKER, N.R.; THOMAS, H. (ed.). Crop photosynthesis. Amsterdan: Elsevier Sciense, 1992. p.177-211.

BENINCASA, M.M.P. Análise de crescimento de plantas: noções básicas. Jaboticabal: FUNEP, 2003. $41 \mathrm{p}$.

BERNARDES, M.S. Fotossíntese no dossel das plantas cultivadas. In: CASTRO, P. R. C.; FERREIRA, S.O.; YAMADA, T. (ed.). Ecofisiologia da produção agrícola. Piracicaba: Associação Brasileira para Pesquisa da Potassa e do Fosfato, 1987. p.13-45.

BLUM, A.; MAYER, J.; GOZLAN, G. Infrared thermal sensing of plant canopies as a screening technique for dehydration avoidance in wheat. Field Crops Research, Amsterdam, v.5, p.137-146, 1982.

BRIGGS, G.E.; KIDD, M.A.; WEST, A.R.C.S. A quantitative analysis of plant growth. Annals of Applied Biology, Oxford, v.7, p.202-223, 1920.

CAMPOSTRINI, E.; YAMANISHI, O.K. Estimation of papaya leaf área using the cental vein length. Scientia Agricola, Piracicaba, v.58, n.1, p.39-42, 2001.
CAN, H.Z.; AKSOY, U. Seasonal and diurnal photosynthetic behaviour of fig (Ficus carica L.) under semi-arid climatic conditions. Acta Agriculturae Scandinavica, Stockholm, v.57, n.4, p.297-306, 2007.

CASALI, V.W.D. Banco de germoplasma de hortaliças. Viçosa: UFV, 1969. 8 p. Mimeografado.

CETESB. Significado ambiental e sanitário das variáveis de qualidade das águas e dos sedimentos e metodologias analíticas e de amostragem. São Paulo, 2009. (Relatório de Qualidade das Águas Interiores do Estado de São Paulo). Disponível em: http://www.cetesb. sp.gov.br. Acesso em: jan. 2016.

CHAVES, M.M.; COSTA, M.; SAIBO, N.J.M. Recent advances in photosynthesis under drought and salinity. Advances in Botanical Research, New York, v.57, p.49104, 2011.

COMETTI, N.N.; MATIAS, G.C.S.; ZONTA, E.; MARY, W.; FERNANDES, M.S. Efeito da concentração da solução nutritiva no crescimento da alface em cultivo hidropônicosistema NFT. Horticultura Brasileira, Brasília, DF, v. 26, p. 262-267, 2008.

CORREA, L.S.; BOLIANI, A.C. Cultura da figueira, do plantio à comercialização. Ilha Solteira: FAPESP, 1999. 259p.

COSTA, M.G.S.; CORREIA, E.C.S.S.; REIS, L.L.; WILCKEN, S.R.S. Reação de figueiras a três espécies de nematoides-das-galhas. Revista Brasileira de Fruticultura, Jaboticabal, v.37, n.3, p.617-622, 2015.

DALASTRA, I.M.; PIO, R.; CAMPAGNOLO, M.A.; DALASTRA, G.M.; CHAGAS, E.A.; GUIMARÃES, V.F. Épocas de poda na produção de figos verdes 'Roxo de Valinhos' em sistema orgânico na região oeste do Paraná. Revista Brasileira de Fruticultura, Jaboticabal, v.31, n.2, p.447-453, 2009.

FERRARI, T.B.; FERREIRA, G.; ZUCARELI, V.; BOARO, C.S.F. Efeito de reguladores vegetais nos índices da análise de crescimento de plântulas de maracujazeirodoce (Passiflora alata Curtis). Biotemas, Florianópolis, v.21, p.45-51, 2008.

FERREIRA, D. F. Sisvar: a Guide for its Bootstrap procedures in multiple comparisons. Ciência e Agrotecnologia, Lavras, v.38, n.2, p.109-112, 2014. 
FLEXAS, J.; BOTA, J.; GALMÉS, J.; MEDRADO, H.; RIBASCARBÓ, M. Keeping a positive carbon balance under adverse conditions: responses of photosynthesis and respiration to water stress. Physilogia Plantarum, Copenhagem, v.57, p.343-352, 2006.

FRANKHAM, R. Genetics and extinction. Biological Conservation, Essex, v.126, p.131-140, 2005.

GOËAU, H.; BONNET, P.; JOLY, A.; BAKI'C, V.; BARBE, J.; YAHIAOUI, I.; SELMI, S.; CARRE, J.; BARTHELEMY, D.; BOUJEMAA, N. PlantNet mobile app. In: ACM INTERNATIONAL CONFERENCE ON MULTIMEDIA, 21., 2013, Barcelona. Proceedings [...]. p.423-424.

GOMIDE, C.A.M.; GOMIDE, J.A., ALEXANDRINO, E. Índices morfogênicos e de crescimento durante o estabelecimento e a rebrotação do capim-mombaça (Panicum maximum Jacq.). Revista Brasileira de Zootecnia, Viçosa, MG, v.32, n.4, p.795-803, 2003.

HUANG, P.; FELDMAN, M.; SCHRODER, S.; BAHRI, B.A.; DIAO, X.; ZHI, H.; ESTEP, M.; BAXTER, I.; DEVOS, K.M.; KELLOGG, E.A. Population genetics of Setaria viridis, a new model system. Molecular Ecology, Oxford, v.23, p.4912-4925, 2014.

KOLIVAND, H.; FERN, B.M.; RAHIM, M.S.M.; SULONG, G.; BAKER, T.; TULLY, D. An expert botanical feature extraction technique based on phenetic features for identifying plant species. PLoS ONE, San Francisco, v.13, n.2, e0191447, 2018.

LARCHER, W. Ecofisiologia vegetal. São Carlos: RIMA, 2000.

LEONEL, S; TECCHIO, M.A. Produção de figueira submetida a diferentes épocas de poda e irrigação. Revista Brasileira de Fruticultura, Jaboticabal, v.30, n.4, p.10151021, 2008.

MARTINS, G.; VASCONCELLOS, E.F.C.; LUCCHESI, A.A.. Correlações entre parâmetros da análise de crescimento de cultivares de tomateiro (Lycopersicon esculentum Mill.). Anais da Escola Superior de Agricultura Luiz de Queiroz, Piracicaba, v.42, n.2, p.401-428, 1985.

MORAIS, R.R.; ROSSI, L.M.B.; HIGA, R.C.V. Trocas gasosas de plantas jovens de taxi-branco submetidas à variação de temperatura foliar e suspensão da irrigação. Ciência Florestal, Viçosa, MG, v.5, n.1, p.97104, 2017.
NASS, L.L. Recursos genéticos vegetais. Brasília: Embrapa Recursos Genéticos e Biotecnologia, 2007. $858 \mathrm{p}$.

NOGUEIRA, O. L.; FIGUERÊDO, F. J. C.; MULLER, A. A. Sistema de produção do açaí. Belém: Embrapa Amazônia Oriental, 2006. (Sistemas de Produção, 4)

PEREIRA, F. M. Cultura da figueira. Piracicaba: Livro Ceres, 1981. 730p.

PIGÉ, L.G.; SALAGER, J.L.; HOSSAERT-MCKEY, M.; ROY, J. Carbon allocation to volatiles and other reproductive componentsin male Ficus carica (Moraceae). American Journal of Botany, Lancaster, v.88, p.22142220, 2001.

PIMENTEL, C. Metabolismo de carbono na agricultura tropical. Seropédica: Edur, 1998. 150p.

PLATT, A.; HORTON, M.; HUANG, Y.S.; LI, Y.; ANASTASIO, A.E.; MULYATI, N.W. The scale of population structure in Arabidopsis thaliana. PloS Genetics, San Francisco, v.6, e1000843, 2010.

RAIJ, B.V.; CANTARELLA, H.; QUAGGIO, J.A.; FURLANI, A.M.C. Recomendações de adubação e calagem para o Estado de São Paulo. Campinas: Instituto Agronômico/Fundação IAC, 1997. p. 285. (Boletim Técnico, 100).

SILVA, A.C.; LEONEL, S.; SOUZA, A.P.; DOMINGOS, J.R.; DUCATT, C. Trocas gasosas e ciclo fotossintético da figueira 'Roxo de Valinhos'. Ciência Rural, Santa Maria, v.40, n.6, p.1270-1276, 2010.

SILVA, L.C.; BELTERÃO, N.E.M.; AMORIM NETO, M.S. Análise do crescimento de comunidades vegetais. Campina Grande: EMBRAPA, 2000. 18 p. (Circular Técnica)

SOUZA, A.P.; SILVA, A.C.; LEONEL, S.; ESCOBEDO, J.F. Temperaturas basais e soma térmica para a figueira podada em diferentes épocas. Revista Brasileira de Fruticultura, Jaboticabal, v.31, n.2, p.314-322, 2009.

TING, I.P.; HANN, J.; HOLBROOK, N.M.; PUTZ, F.E.; STERNBERG, L. DA S. L.; PRICE, D.; GOLDSTEIN, G. Photosynthesis in hemiepiphytic species of Clusia and Ficus. Oecologia, Berlin, v.74, p.339-346, 1987.

ZOTZ, G.; PATIÑO, S.; TYREE, M.T. Water relations and hydraulic architecture of woody hemiepiphytes. Journal of Experimental Botany, Oxford, v.48, n.10, p.18251833, 1997. 